\title{
Spatial and Temporal Variations of Gaseous and Particulate Pollutants in Six Sites in Tibet, China, during 2016-2017
}

\author{
Pengfei Chen ${ }^{1}$, Shichang Kang ${ }^{1,2 *}$ Junhua Yang ${ }^{1}$, Tao Pu ${ }^{1}$, Chaoliu $\mathrm{Li}^{2,3}$, Junming Guo ${ }^{1}$, \\ Lekhendra Tripathee ${ }^{1}$ \\ ${ }^{1}$ State Key Laboratory of Cryospheric Science, Northwest Institute of Eco-Environment and Resources, Chinese Academy \\ of Sciences (CAS), Lanzhou 730000, China \\ ${ }^{2}$ CAS Center for Excellence in Tibetan Plateau Earth Sciences, Beijing 100085, China \\ ${ }^{3}$ Key Laboratory of Tibetan Environment Changes and Land Surface Processes, Institute of Tibetan Plateau Research, \\ CAS, Beijing 100101, China
}

\begin{abstract}
Long-term air quality data with high temporal and spatial resolutions are necessary to understand some processes influencing air quality and corresponding environmental and health effects. In this study, spatiotemporal variations of $\mathrm{PM}_{2.5}, \mathrm{PM}_{10}, \mathrm{SO}_{2}, \mathrm{NO}_{2}, \mathrm{CO}$, and $\mathrm{O}_{3}$ were investigated over a one-year period (June 2016-May 2017) at six sites of the Tibetan Plateau (TP). The annual mean concentrations of $\mathrm{PM}_{2.5}$ in all cities except Nagchu were below the Grade II standard $\left(35 \mu \mathrm{g} \mathrm{m}^{-3}\right)$, and the values in Nagri and Nyingchi were even less than the Grade I standard $\left(15 \mu \mathrm{g} \mathrm{m}^{-3}\right)$. PM 10 concentrations showed similar distribution pattern with $\mathrm{PM}_{2.5}$. Evident seasonal variations of $\mathrm{PM}_{2.5}, \mathrm{PM}_{10}, \mathrm{SO}_{2}, \mathrm{NO}_{2}$, and $\mathrm{CO}$ concentrations were observed, with the highest seasonal average value being in winter followed by fall, spring, and summer, in descending order. By contrast, the 8-h $\mathrm{O}_{3}$ concentration showed an opposite seasonal variation because the $\mathrm{O}_{3}$ depended on lots of factors such as stratospheric incursions, weather conditions, and intensity of solar radiation. The diurnal trends of $\mathrm{PM}_{2.5}, \mathrm{PM}_{10}, \mathrm{SO}_{2}, \mathrm{NO}_{2}$, and $\mathrm{CO}$ concentrations in study region generally showed a flat "W" shape with two peaks occurring around noon (10:00-12:00) and midnight (21:00-23:00); these peaks were found to be affected by emission sources and weather conditions. However, the $\mathrm{O}_{3}$ concentration trends did not significantly differ among the six regions, with the maximum concentration being in the afternoon. In sum, cities on the TP showed slightly higher pollution levels in regions affected by anthropogenic activities such as Lhasa and Nagchu, whereas other cities showed good air quality. Beside long-range transport pollutants from surrounding regions, local emissions (e.g., biomass burning, religious activities) also contributed much to the atmospheric pollutants. This study provides a basis for the formulation of future urban air pollution control measures on the TP.
\end{abstract}

Keywords: $\mathrm{PM}_{2.5}$; Ozone; Air pollution; Distribution; Tibetan Plateau.

\section{INTRODUCTION}

As the world's most populous developing country, China has experienced severe air pollution with considerable increases of air pollutants owing to rapid economic development and increasing urbanization in recent decades (Chan and Yao, 2008; Guo et al., 2014; Du and Li, 2016; Lin et al., 2018; Zhao et al., 2018). The Asian Development Bank reported that $70 \%$ of the most polluted cities in the world are situated in China (Bapna, 2012). On the basis of the Global Burden of Disease Study, 4.2 million deaths

\footnotetext{
* Corresponding author.

Tel.: +86-0931-4967368

E-mail address: shichang.kang@lzb.ac.cn
}

have been caused by air pollution in 2015, among which 1.6 million individuals were from China (Hu et al., 2014; Forouzanfar et al., 2016; Landrigan, 2016). One study reported that ambient $\mathrm{PM}_{2.5}$ accounts for $15.5 \%$ of all the causes of death in China (Song et al., 2017a). The elevated $\mathrm{PM}_{2.5}$ and ozone concentration significantly affects human health and threatens sustainable development of China (Liu et al., 2017b; Zhao et al., 2018). Therefore, these air quality data are requisite to understand pollution status and assess the human health risks of China (Wang et al., 2014).

The Chinese Ministry of Environmental Protection start to release hourly averaged concentrations of $\mathrm{PM}_{2.5}, \mathrm{PM}_{10}$, $\mathrm{SO}_{2}, \mathrm{NO}_{2}, \mathrm{CO}$, and $\mathrm{O}_{3}$ recorded from the monitoring stations situated in over hundred cities in China from Jan 2013. The characteristics of these six pollutants and their influence factors have been widely studied in terms of released monitoring data $\mathrm{Hu}$ et al., 2014; Wang et al., 
2014; Huang et al., 2015; Ma and Jia, 2016; Zhang et al., 2016; Guan et al., 2017; He et al., 2017; Song et al., 2017b; Yin et al., 2017a; Zhou et al., 2017; Zhao et al., 2018). These researches have revealed that the pollutant concentrations in cold months are much higher than those in summer; this is in contrast to the case of ozone. Some studies suggested that the frequent heavy haze-fog episodes in China are mainly caused by large amount of air pollutant emissions during the cold season (Wang et al., 2013; Tan et al., 2016; Yin et al., 2017a). Other studies have demonstrated that weather conditions also play an important role in affecting the pollutants diffusion. In addition, high mountains like Qinghai-Tibet Plateau are considered to be barrier which can block pollutants transporting from South and East Asia (Cao et al., 2015; Jia et al., 2015; Zheng et al., 2015; Xu et al., 2016; Ding et al., 2017; Yin et al., 2017a). However, most of the previous studies simply analyzed the characteristics of pollutants in central and eastern China (Chai et al., 2014; Hu et al., 2014; Wang et al., 2014; Xie et al., 2015; Zhao et al., 2016; He et al., 2017; Wang et al., 2018), whereas little has been reported in western China especially the Tibetan Plateau (TP) which is located in large-scale complex terrain.

The TP is one of the world's least scientifically studied regions regarding air pollutant concentration, variation, transportation, and health risk assessment. Pollutant emissions from the TP itself are relatively less compared with densely populated and industrialized parts of East of China and South Asia (Chen et al., 2018a). Local residents in most parts of the TP depend on traditional agriculture and animal husbandry for their livelihood, whereas the proportion of industry accounts for only $8 \%$ of the GDP of this huge area (http://www.tibet.stats.gov.cn/). Therefore, the TP is known as a remote background region worldwide. However, numerous recent researches have pointed out that air pollutants emitted from South Asia can reach this remote region by long-range transport (Cong et al., 2015; Lüthi et al., 2015; Kang et al., 2016; Li et al., 2016a; Chen et al., 2018b; Wu et al., 2018). In addition, local anthropogenic emissions such as yak dung burning and religious incense burning also contributes significantly to the atmospheric environment (Kang et al., 2009; Gong et al., 2011; Li et al., 2012; Chen et al., 2015; Xiao et al., 2015; Li et al., 2016a; Chen et al., 2018a).

This study presents the results of six criteria air pollutants in Lhasa, Ngari, Qamdo, Nyingchi, Nagchu, and Shigatse during 2016-2017. The main objectives are (1) to investigate the concentrations of the six criteria pollutants in the TP, and (2) to identify their seasonal variations and the relationships among the pollutants.

\section{METHODS AND DATA}

\section{Site Information}

Six sites, namely, Lhasa, Ngari, Qamdo, Nyingchi, Nagchu, and Shigatse, were chosen in this study (Fig. 1 and Table 1). Ngari, located on the border of China and Kashmir, India, is controlled by the seasonal shifting of atmospheric circulations, with Indian monsoon controlling in summer, whereas the westerlies predominated in other seasons (Gong et al., 2015). The region is covered by bare soil or grassland. The annual average temperature is approximately $2^{\circ} \mathrm{C}$ and annual precipitation was approximately $90 \mathrm{~mm}$ for the period 2010-2013. About 80\% of rainfall occurs in the summer (June-September). Qamdo, located in the eastern of the TP, with an average elevation of $3500 \mathrm{~m}$, has a semi-arid monsoon climate, which is dry and cold in winter and moist and moderately hot in summer. The annual average temperature is $7.6^{\circ} \mathrm{C}$ and precipitation is $400-600 \mathrm{~mm}$. Nyingchi city, located downstream of the

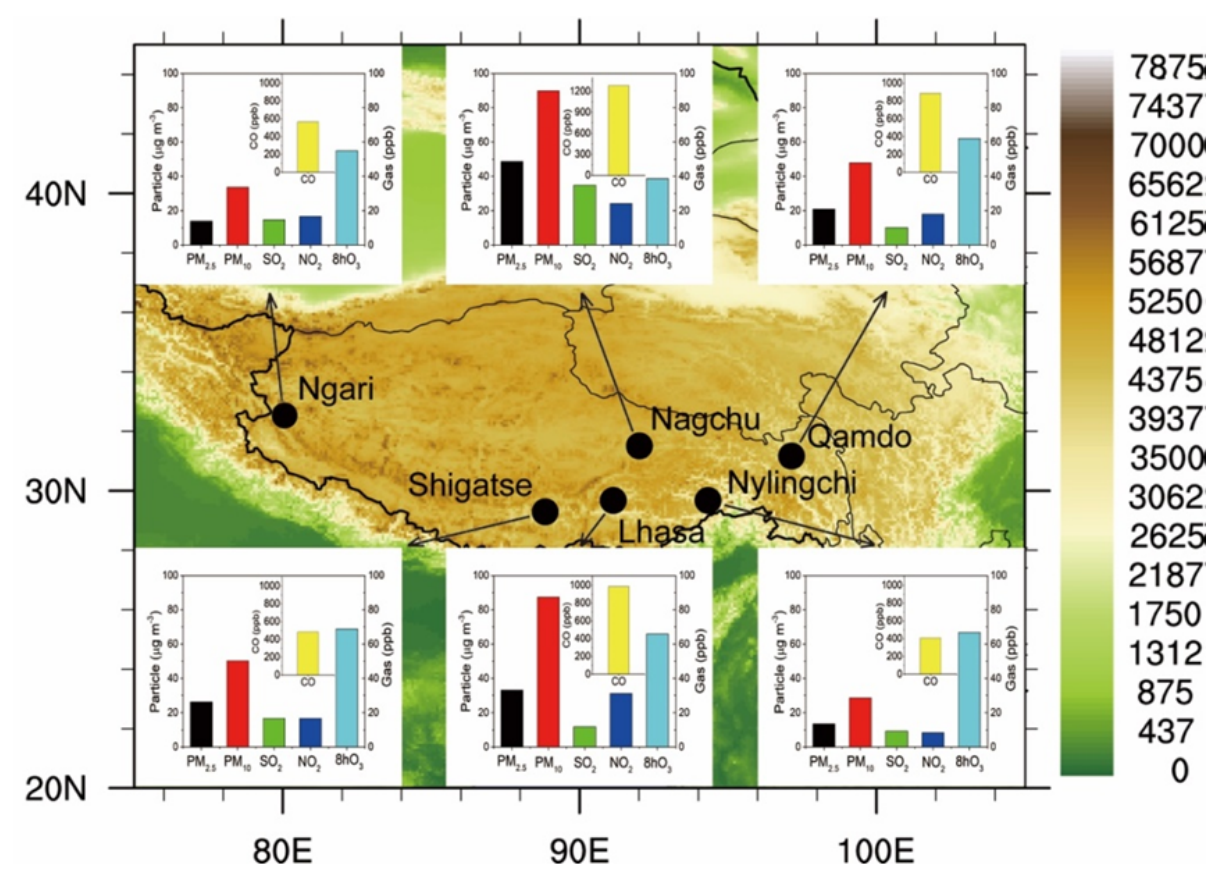

Fig. 1. Geographical map and locations of the cities in the TP. 
Table 1. Detailed information of study regions on the TP.

\begin{tabular}{lllll}
\hline City & Latitude/degree & Longitude/degree & Population/million & GDP/Billion \\
\hline Lhasa & $29^{\circ} 39.16^{\prime}$ & $91^{\circ} 10.32^{\prime}$ & 0.90 & 42.50 \\
Ngari & $32^{\circ} 30.09^{\prime}$ & $80^{\circ} 06.34^{\prime}$ & 0.09 & 2.89 \\
Qamdo & $31^{\circ} 08.46^{\prime}$ & $97^{\circ} 10.33^{\prime}$ & 0.73 & 5.49 \\
Nyingchi & $29^{\circ} 38.96^{\prime}$ & $94^{\circ} 21.72^{\prime}$ & 0.23 & 7.24 \\
Nagchu & $31^{\circ} 28.58^{\prime}$ & $92^{\circ} 03.08^{\prime}$ & 0.50 & 10.62 \\
Shigatse & $29^{\circ} 16.03^{\prime}$ & $88^{\circ} 52.83^{\prime}$ & 0.75 & 12.45 \\
\hline
\end{tabular}

YarlungZangbo River, with an average elevation of $3100 \mathrm{~m}$, has an annual average temperature of $8.7^{\circ} \mathrm{C}$ and precipitation of $650 \mathrm{~mm}$. Lhasa is the capital of Tibet autonomous region. It is a famous historic tourist city and currently undergoing rapid urbanization and tourism development (Li and Wang, 2014; Li et al., 2016b; Li et $a l ., 2018)$. The temperature ranges from -5.7 to $21.2^{\circ} \mathrm{C}$ (average: $9.0^{\circ} \mathrm{C}$ ), and the relative humidity range $7 \%-75 \%$ with an average of $38.7 \%$ (Wan et al., 2016). The annual average precipitation is approximately $400 \mathrm{~mm}$ with most occurring during summer due to influence of Indian monsoon. Nagchu, located in the central of the TP, has an average temperature of $-2^{\circ} \mathrm{C}$ and an annual mean precipitation of approximately $420 \mathrm{~mm}$. Shigatse, known as the Tibet's barn, is the second largest city in the TP. It has an elevation of approximately $3800 \mathrm{~m}$ and a population of about 720,000. Shigatse contributes approximately half of the total agricultural output of the Tibet Autonomous Region (Yang et al., 2016). The annual mean precipitation is approximately $433 \mathrm{~mm}$, and the average temperature and wind speed are $2.5^{\circ} \mathrm{C}$ and $1.43 \mathrm{~m} \mathrm{~s}^{-1}$ in dry season and $14.3^{\circ} \mathrm{C}$ and $1.74 \mathrm{~m} \mathrm{~s}^{-1}$ in wet season, respectively (Yang et al., 2016).

\section{Air Quality Data}

In order to understand the characteristics of these six pollutants in cities of the TP, real-time hourly averaged monitoring data of $\mathrm{PM}_{2.5}, \mathrm{PM}_{10}, \mathrm{SO}_{2}, \mathrm{NO}_{2}, \mathrm{CO}$, and $\mathrm{O}_{3}$ from June 2016 to May 2017 were obtained from the China National Environmental Monitoring Center (CNEMC) (http://113.108.142.147:20035/emcpublish/). Detailed information about the data obtaining were described by previous researches (Hu et al., 2014; Wang et al., 2014; Zhao et al., 2018). Briefly, automated monitoring systems were set at each site to monitor the ambient concentration of these six criteria pollutants according to the China Environmental Protection Standards HJ 193-2013 (http://www.es.org.cn/download/2013/7-12/2627-1.pdf) and HJ 655-2013 (http://www.es.org.cn/download/2013/712/2626-1.pdf). Two methods including micro-oscillating balance and $\beta$-absorption are used for measuring particulate matter $\left(\mathrm{PM}_{2.5}\right.$ and $\left.\mathrm{PM}_{10}\right)$ concentrations; and chemiluminescence method, ultra-violet (UV) fluorescence method, and UV-spectrophotometry method are used for $\mathrm{NO}_{2}, \mathrm{SO}_{2}$, and $\mathrm{O}_{3}$ concentrations, respectively. For $\mathrm{CO}$, both the nondispersive infrared absorption method and the gas filter correlation-infrared absorption method are used. Before publish these hourly averaged data, a sanity check was conducted at each station to remove problematic data points. The 8-h $\mathrm{O}_{3}$ concentrations were calculated when there were valid data for at least $6 \mathrm{~h}$ for every $8 \mathrm{~h}$ during that day, whereas the mean daily concentrations for other five pollutants were calculated only when there were valid data for more than $20 \mathrm{~h}$ (Hu et al., 2014; Wang et al., 2014; Zhao et al., 2018).

\section{RESULTS AND DISCUSSION}

\section{Overview of Air Pollutants}

The annual average concentrations of the six criteria pollutants in six cities of the TP were given in Table 2 and Fig. 1. The $\mathrm{PM}_{2.5}$ concentrations ranged 13.4-48.7 $\mu \mathrm{g} \mathrm{m}^{-3}$, with Nagchu and Nyingchi having the highest and lowest concentrations, respectively. Lhasa, Shigatse, and Qamdo showed medium values of approximately $25 \mu \mathrm{g} \mathrm{m}{ }^{-3}$. $\mathrm{PM}_{2.5}$ concentrations in all cities except Nagchu were below the Grade II standard $\left(35 \mu \mathrm{g} \mathrm{m}^{-3}\right)$, and the values in Nagri and Nyingchi were even less than the Grade I standard $\left(15 \mu \mathrm{g} \mathrm{m}^{-3}\right) . \quad \mathrm{PM}_{10}$ concentrations exhibited a similar distribution pattern, with high values occurring in Nagchu and Lhasa, which exceeded the Grade II standard $\left(70 \mu \mathrm{g} \mathrm{m}^{-3}\right)$ and low values in Nagri and Nyingchi, which were below the Grade I standard $\left(40 \mu \mathrm{g} \mathrm{m}^{-3}\right)$. Nagchu had the highest $\mathrm{SO}_{2}$ concentrations $(34.9 \pm 10.8 \mathrm{ppb})$, which exceeded the Grade II standard (21 ppb), whereas other five cities had similar $\mathrm{SO}_{2}$ concentrations of approximately $10 \mathrm{ppb}$. Lhasa had the highest $\mathrm{NO}_{2}$ concentrations, followed by Nagchu, both exceeding the Grade II standard (20 ppb), whereas Shigatse, Qamdo, and Nagri had similar values of approximately $16 \mathrm{ppb}$ and Nyingchi had the lowest concentration $(8.31 \mathrm{ppb})$. The annual average $\mathrm{CO}$ concentrations ranged from $408 \mathrm{ppb}$ (Nyingchi) to $1283 \mathrm{ppb}$ (Nagchu). Nagchu, Lhasa, and Qamdo had higher values than those of the other three cities. The annual average 8-h $\mathrm{O}_{3}$ concentrations showed similar values in all cities except Nagchu. Spatial distributions of these six pollutants indicated that regional high concentrations were mainly concentrated on densely populated cities of the TP with higher GDP (Table 1).

The $\mathrm{PM}_{2.5} / \mathrm{PM}_{10}$ ratios were different among these six sites with the highest and the lowest values observed in Nagchu and Lhasa, respectively (Table 2). Shigatse was also found to have higher $\mathrm{PM}_{2.5} / \mathrm{PM}_{10}$ ratio than $52 \%$ which are comparable with those in some other regions such as North China Plain, west of Sichuan and Xi'an (Wang et al., 2014; Song et al., 2017b; Zhao et al., 2018). However, the values in other three cities were significantly lower than those obtained in urban cities such as Beijing, Shanghai, 
Table 2. Annual average concentrations of the six criteria pollutants in six cities of the TP.

\begin{tabular}{|c|c|c|c|c|c|c|c|}
\hline & $\frac{\mathrm{PM}_{2.5}}{\mu \mathrm{g} \mathrm{m}^{-3}}$ & $\frac{\mathrm{PM}_{10}}{\mu \mathrm{g} \mathrm{m}^{-3}}$ & $\frac{\mathrm{SO}_{2}}{\mathrm{ppb}}$ & $\begin{array}{l}\mathrm{NO}_{2} \\
\mathrm{ppb}\end{array}$ & $\begin{array}{l}\mathrm{CO} \\
\mathrm{ppb}\end{array}$ & $\begin{array}{l}8 \mathrm{hO}_{3} \\
\mathrm{ppb}\end{array}$ & $\begin{array}{l}\mathrm{PM}_{2.5} / \mathrm{PM}_{10} \\
\%\end{array}$ \\
\hline Lhasa & $33.1 \pm 20.2$ & $87.3 \pm 69.4$ & $11.8 \pm 5.7$ & $31.2 \pm 21.6$ & $985 \pm 734$ & $65.9 \pm 30.7$ & 37.9 \\
\hline Shigatse & $26.3 \pm 20.3$ & $50.2 \pm 39.8$ & $16.6 \pm 5.3$ & $16.6 \pm 13.3$ & $484 \pm 218$ & $68.8 \pm 24.9$ & 52.4 \\
\hline Ngari & $13.9 \pm 11.8$ & $33.6 \pm 30.3$ & $14.7 \pm 9.32$ & $16.6 \pm 13.6$ & $565 \pm 201$ & $54.9 \pm 17.5$ & 41.5 \\
\hline Nagchu & $48.7 \pm 46.4$ & $89.8 \pm 72.4$ & $34.9 \pm 10.8$ & $24.1 \pm 16.9$ & $1283 \pm 763$ & $38.7 \pm 15.3$ & 54.3 \\
\hline Qamdo & $20.9 \pm 16.9$ & $47.9 \pm 41.2$ & $10.1 \pm 2.87$ & $17.9 \pm 18.3$ & $888 \pm 391$ & $62.1 \pm 30.0$ & 43.8 \\
\hline Nyingchi & $13.4 \pm 7.7$ & $28.6 \pm 20.8$ & $9.2 \pm 2.4$ & $8.31 \pm 5.9$ & $408 \pm 139$ & $66.7 \pm 22.9$ & 46.7 \\
\hline North China Plain ${ }^{a}$ & $84.5 \pm 9.6$ & $138.9 \pm 16.8$ & $39.0 \pm 8.5$ & $49.7 \pm 1.6$ & 1330 & $54.9 \pm 0.3$ & 56 \\
\hline $\mathrm{YRD}^{\mathrm{a}}$ & $53.7 \pm 5.6$ & $83.9 \pm 7.1$ & $20.9 \pm 2.7$ & $39.5 \pm 1.1$ & 900 & $63.2 \pm 1.3$ & 63 \\
\hline West of Sichuan ${ }^{b}$ & $24.3 \pm 5.5$ & $45.0 \pm 12.7$ & $23.6 \pm 10$ & $23.7 \pm 8.7$ & $1000 \pm 400$ & $76.0 \pm 16.1$ & 54 \\
\hline Beijing $^{c}$ & $87 \pm 67$ & $109 \pm 62$ & $9 \pm 8$ & $25 \pm 11$ & $1068 \pm 668$ & $45 \pm 27$ & 79.8 \\
\hline Shanghai ${ }^{\mathrm{c}}$ & $56 \pm 41$ & $80 \pm 47$ & $7 \pm 5$ & $20 \pm 9$ & $704 \pm 256$ & $48 \pm 21$ & 70 \\
\hline Guangzhou $^{\mathrm{c}}$ & $52 \pm 28$ & $72 \pm 35$ & $7 \pm 3$ & $24 \pm 10$ & $821 \pm 185$ & $45 \pm 24$ & 72.2 \\
\hline Xi'an ${ }^{\mathrm{c}}$ & $97 \pm 83$ & $181 \pm 127$ & $14 \pm 10$ & $25 \pm 9$ & $1569 \pm 752$ & $37 \pm 20$ & 53.6 \\
\hline
\end{tabular}

Note YRD: Yangtze River Delta; ${ }^{a}$ reported data from Jan 2014 to Dec 2016 (Song et al., 2017b); ${ }^{b}$ reported data from Jan 2015 to Feb 2017 (Zhao et al., 2018); ${ }^{\text {c }}$ reported data from Mar 2013 to Feb 2014 (Wang et al., 2014).

and Guangzhou (Wang et al., 2014). In general, the average $\mathrm{PM}_{2.5} / \mathrm{PM}_{10}$ ratio was approximately $46.1 \%$ in the six sites, which is significantly lower than the ratios obtained from the literature, namely, 65\% in China before 2012 (Zhou et al., 2016; $\mathrm{Xu}$ et al., 2017), 58\% in 31 Chinese provincial capital cities during 2014-2015 (He et al., 2017), and 56\% in 190 Chinese cities during 2013-2014 (Zhang and Cao, 2015). The case may be in connection with the fact that Tibetan cities are easily affected by dust events such as floating dust, dust storms, and blowing dust, leading to a obvious increase in $\mathrm{PM}_{2.5-10}$ (particle size: $2.5-10 \mu \mathrm{m}$ ) mass concentrations. Previous studies has proved that mineral dust is one of the main aerosol compositions in some regions of the TP (Decesari et al., 2010; Zhang et al., 2001; Kang et al., 2016). And analysis of dust conducted at surrounding deserts (e.g., the Taklimakan, Gobi, and southwest Asian deserts) has also provided evidence for atmospheric particulates transporting on the TP (Huang et al., 2007; Liu et al., 2008; Xia et al., 2008).

As shown in Table 2, the concentrations of six pollutants on the TP are compared with those in other regions in China. The annual average $\mathrm{PM}_{2.5}$ concentrations were only close to those in the Sichuan Basin (Zhao et al., 2018) and considerably lower than those in the NCP, YRD, and in cities of other typically heavily polluted regions (Wang et al., 2014; Song et al., 2017a, b). However, the mean $\mathrm{PM}_{10}$ concentrations of Lhasa and Nagchu were comparable to those of cities such as Shanghai and Guangzhou. Moreover, the annual $\mathrm{SO}_{2}$ concentrations of all cities except Nagchu were lower than those in the NCP and were close to those of the YRD and Sichuan Basin. In addition, concentrations of $\mathrm{NO}_{2}$ and $\mathrm{CO}$ in Lhasa and Nagchu were comparable to those in typical polluted cities. The annual mean $\mathrm{O}_{3}$ concentrations in all six cities were slightly higher than those in other regions of China. These analyses indicate that the air in Lhasa and Nagchu is affected by anthropogenic activities to some extent, whereas other sites show background values.

\section{Temporal Variations}

To better understand the air pollution status on the TP, the monthly averaged pollutant concentrations are shown in Fig. 2. $\mathrm{PM}_{2.5}$ concentrations in the study region exhibited considerable temporal variability, with the highest being in November and December and the lowest during June to August. The concentrations in other months were approximately the same. The elevated $\mathrm{PM}_{2.5}$ concentration in cold season might due to increased fuel burning for residential heating and cooking. In addition, unfavorable weather condition such as few precipitation and slow winds is unfit for air pollutants dilution and dispersion (Chai et al., 2014; Wang et al., 2014). Usually, industrial and vehicle emissions play an important part in some cities for high $\mathrm{PM}_{2.5}$ concentrations. For example, two previous studies reported that iron and steel manufacturing contributed $11 \%$ to $\mathrm{PM}_{2.5}$ concentration in Chengdu during 2011 (Tao et al., 2014) and industrial emissions account for $27 \%$ in Wuhan during 2011-2012 (Cheng et al., 2012). However, the proportion of industry accounts for only $8 \%$ of the GDP of the TP, thus biomass burning and religious activities as well as weather condition might be the main reason for $\mathrm{PM}_{2.5}$ variation.

$\mathrm{PM}_{10}$ concentrations in Lhasa, Shigatse, and Qamdo showed similar seasonal variations as those of $\mathrm{PM}_{2.5}$ concentrations. However, $\mathrm{PM}_{10}$ concentrations were found to be the highest in fall in Nagchu and were did not differ significantly among the four seasons in Ngari and Nyingchi (Fig. 2). $\mathrm{SO}_{2}, \mathrm{NO}_{2}$, and $\mathrm{CO}$ also showed similar seasonal variations, with the highest and lowest values occurred in winter and summer, respectively. The seasonal pattern was found to be a typical feature in East Asia (Wang et al., 2014; Zhao et al., 2018). These seasonal variations were mainly affected by the meteorological conditions and emission sources. Usually, stagnant weather conditions occurred more frequently in winter which characterized by shallow mixing layers, few precipitation and slow winds. This can trap the pollutants emitted by local emissions or transported form other regions and elevating their concentrations near 

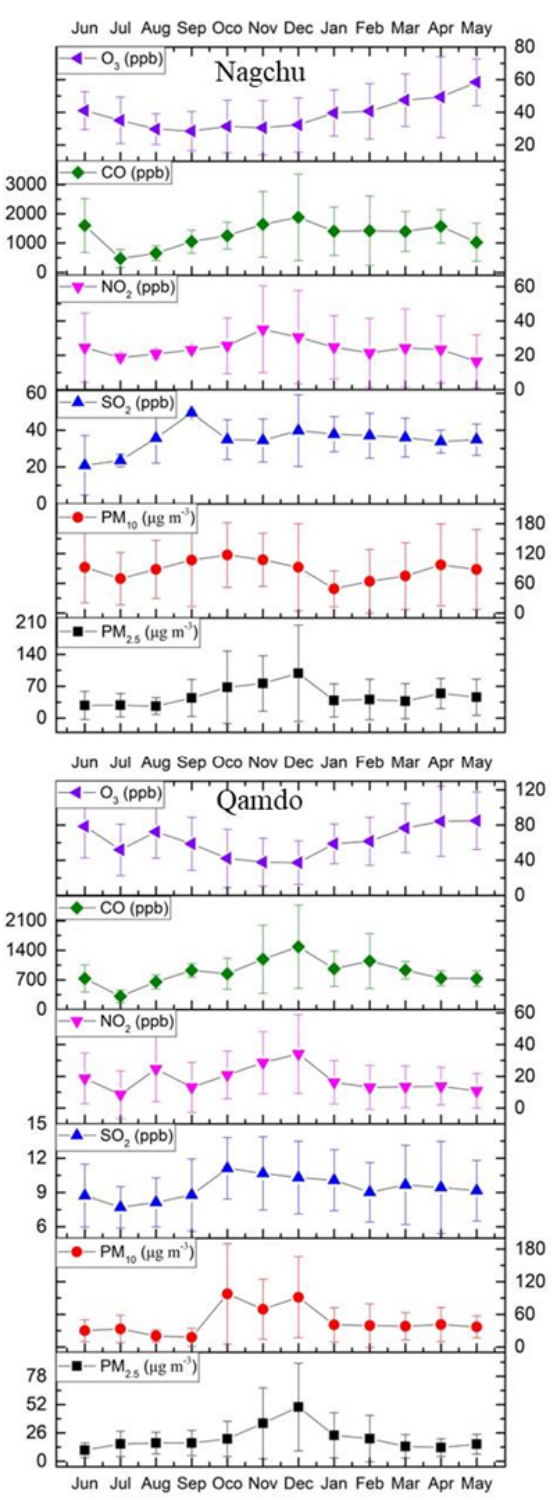

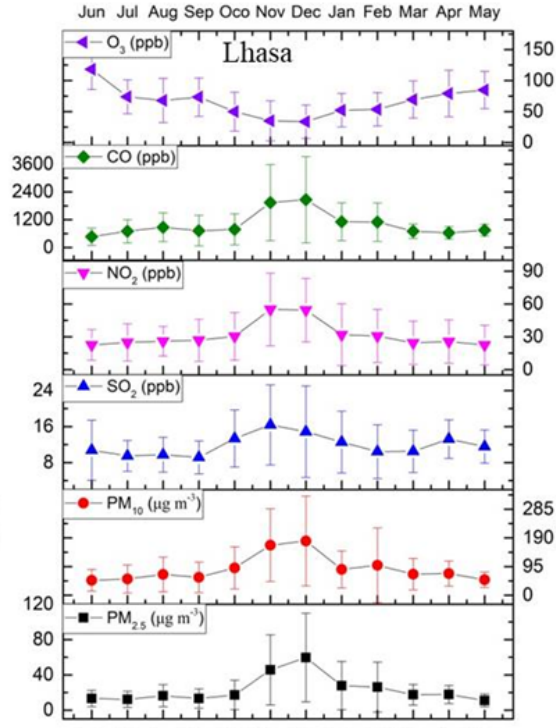

Jun Jul Aug Sep Oco Nov Dec Jan Feb Mar Apr May

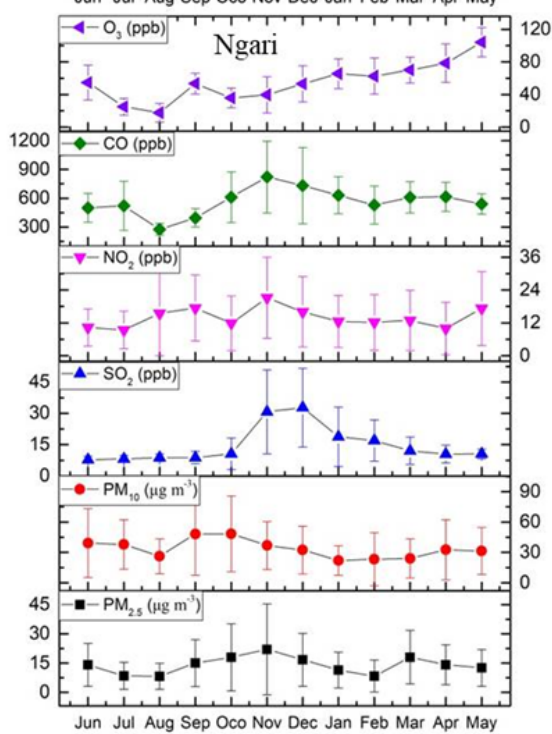

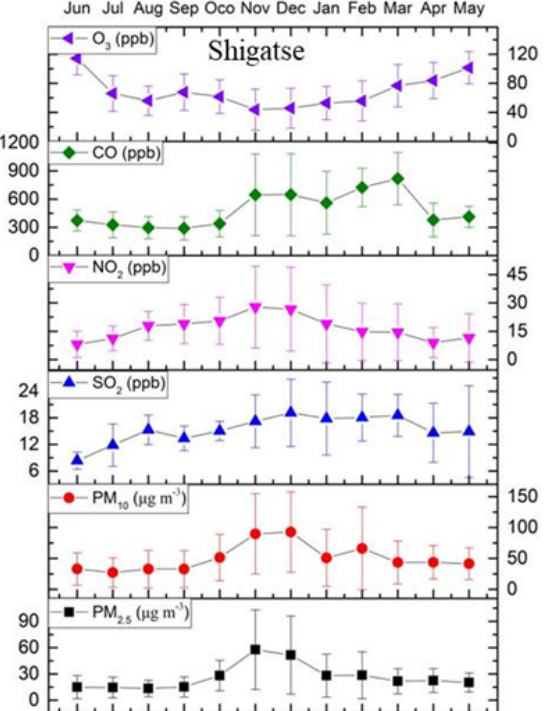

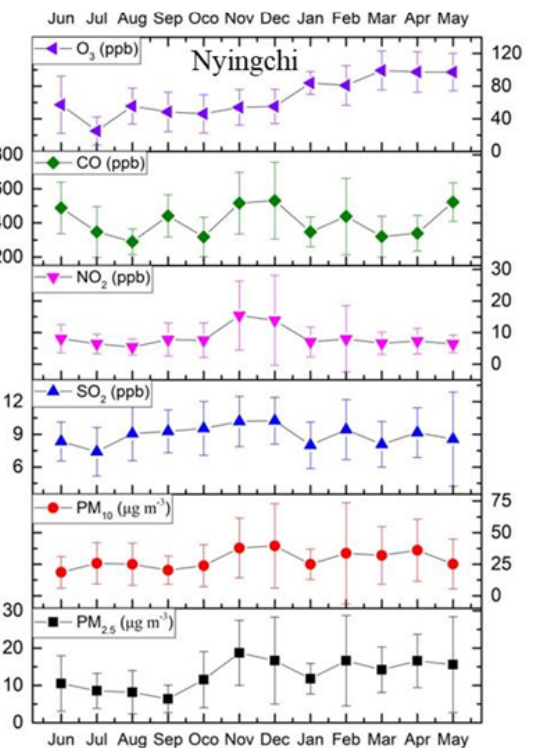

Fig. 2. Mean annual variations of the monthly averages for six criteria air pollutant concentrations in cities of the TP.

the surface (Tai et al., 2010; Wang et al., 2014). Emission source is another important factor influencing the seasonal distributions of pollutants. Previous studies have reported that pollutants emitted from IGP can be transported to the TP (Ji et al., 2015; Li et al., 2016a; Chen et al., 2017; Yang et al., 2018). For example, Yang et al. (2018) simulated the origin of anthropogenic black carbon transported to the TP, which showed that South Asia contributed $40-80 \%$ and $10-50 \%$ of surface black carbon in the non-monsoon and monsoon seasons, respectively. Whereas anthropogenic black carbon from eastern China accounted for less than $10 \%$ in the non-monsoon season but can be up to $50 \%$ in the monsoon season for the northeastern TP. Besides longrange transport pollutants, local emissions such as yak dung combustion also contributed part of pollutants throughout the TP (Chen et al., 2015; Li et al., 2016a). Along with fast development of China during last decades and the setup of Qinghai-Tibet Railway at 2006, the Tibetan Autonomous Region experienced intensively urbanization process, so that fossil combustion had intensively influenced the atmosphere of its urban area (Li et al., 2018). Research based on carbon isotope also provided direct evidence that local biomass burning are important to atmospheric pollution on the TP (Li et al., 2016a). This is further supported by previous researches based on regional climate-atmospheric chemistry model and positive matrix factorization receptor model. For example, Yang et al. (2019) reported the contribution proportions of various emission sources to $\mathrm{PM}_{2.5}$ in western China. The results showed that residential sector was the largest contributor to the $\mathrm{PM}_{2.5}$ concentrations with a contributions ratio of $56.2 \%$, while the transportation and industrial sectors contributed $14.3 \%$ and $17.6 \%$, respectively, in cities of the TP. In addition, the particle phase PAHs sources were quantified using the PMF model in Lhasa city and the results also revealed that biomass burning from local residents was the main source (48.4\%) followed by vehicle emissions and coal combustion (Chen et al., 2018a). 
Ozone concentration in urban regions is largely affected by local weather condition, large-scale circulation, and various emission sources (Shu et al., 2016; Li et al., 2017; Kim et al., 2018). Using the factor separation approach, $\mathrm{Li}$ et al. (2017) suggested that fossil fuel consumption contributed most in $\mathrm{O}_{3}$ formation and is the major causes of severe $\mathrm{O}_{3}$ pollution in eastern China. Furthermore, complex topography also significantly impacts $\mathrm{O}_{3}$ distributions (Kang et al., 2012). However, the effects of emissions and weather condition on $\mathrm{O}_{3}$ concentration have not been sufficiently studied in cities of the TP (Zheng et al., 1998; Cui et al., 2015). The seasonal variation of surface $\mathrm{O}_{3}$ is influenced by many factors including stratospheric intrusion, long-range transport air masses, local vertical mixing, and even deposition (Li et al., 2016c; Wang et al., 2017; Yin et al., 2017b; Zhao et al., 2018). In this study, the 8-h $\mathrm{O}_{3}$ concentration showed an opposite seasonal variation to other pollutants with the highest and the lowest values occurred in late spring-early summer and winter, respectively (Fig. 2). On the TP, the largest stratospheric incursions usually occurred in spring and the planetary boundary layer height is higher at same period which facilitated the impact of downward transport from the stratosphere to surface of these sites. In addition, the late spring to early summer period has more intense solar radiation because the monsoon leads to increased cloudiness in summer. The increased solar radiation promotes the photochemical production of surface $\mathrm{O}_{3}$ in such periods. In winter and fall, the shortwave radiation is weaker than that in other seasons, thus cause relatively low level of $\mathrm{O}_{3}$.

Fig. 3 showed the hourly average concentrations of six pollutants. The trends of $\mathrm{PM}_{2.5}, \mathrm{PM}_{10}, \mathrm{SO}_{2}, \mathrm{NO}_{2}$, and $\mathrm{CO}$ concentrations generally showed a flat "W" shape on the TP with two valleys occurred approximately in the early
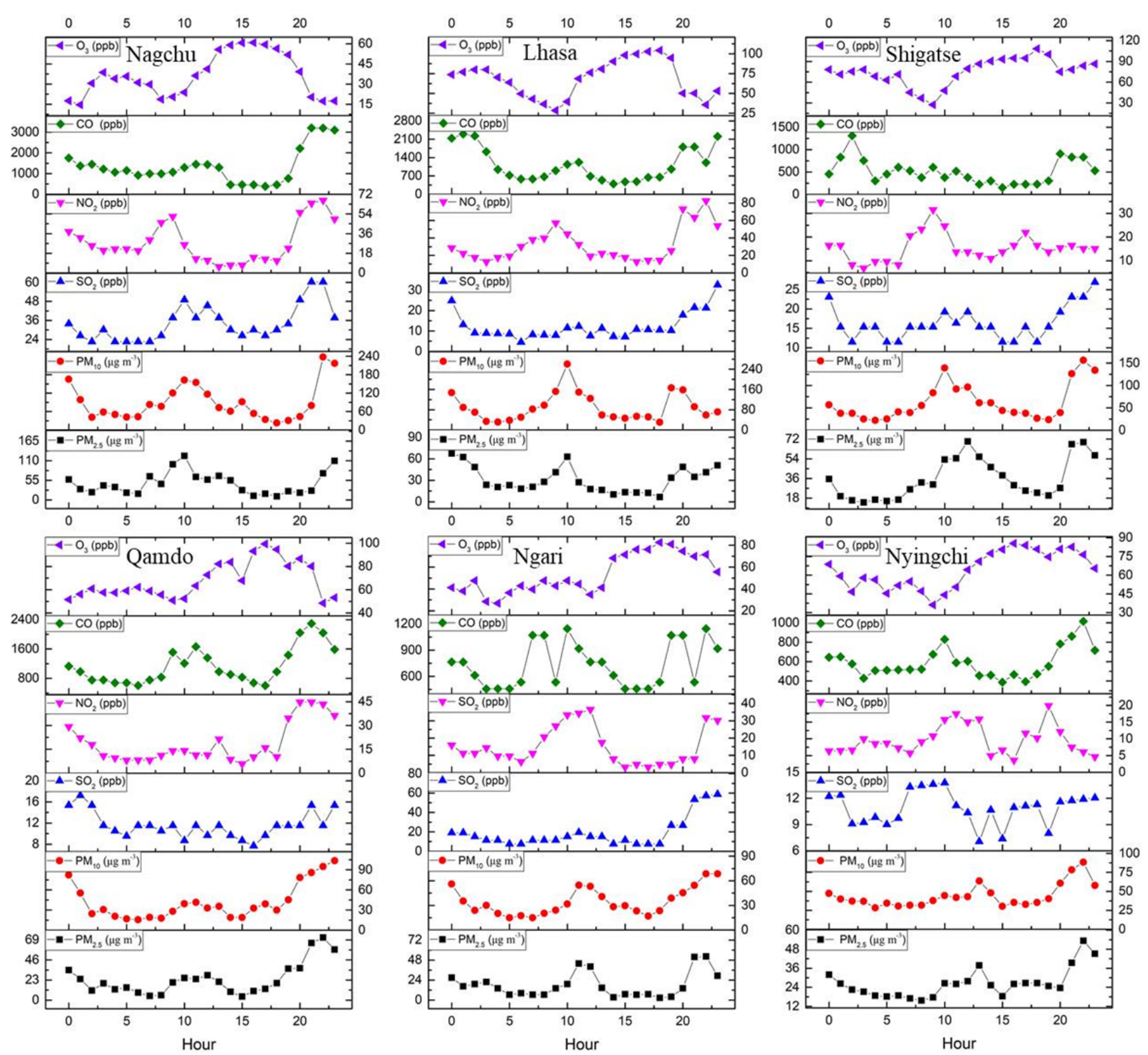

Fig. 3. Mean diurnal variations of the hourly averages of six criteria air pollutants in cities of the TP. 
morning and the late afternoon ( 16:00), respectively. In the early morning, reduced anthropogenic activities and pollutant deposition might be the main reason for low pollutant concentrations; whereas relatively high planetary boundary layer height is conducive to the dispersion and dilution of air pollutants in the late afternoon (Tie et al., 2007; Zhao et al., 2018). Correspondingly, two peaks occurred at noon (10:00-12:00) and night (21:00-23:00), respectively, when the planetary boundary layer height was low and human activity was high, which are conducive to the formation and concentration of pollutants. This pattern differs from those in eastern cities (e.g., Beijing), where have peak pollutant concentrations at 20:00 pm. The time difference between eastern cities and the study region might be the reason for two variation patterns. Notably, the daytime $\mathrm{PM}_{2.5}$ concentrations were somewhat lower than those during nighttime. It seems that substantially enhanced local emissions (e.g., religious activities, biomass burning for heating and cooking) after sunset cause this diurnal variation of $\mathrm{PM}_{2.5}$ concentrations on the TP (Li et al., 2018).

In the present study, it was observed that the $\mathrm{O}_{3}$ concentrations did not show considerable differences among the six regions; the maximum concentration was in the afternoon (Fig. 3). Wind speed and planetary boundary layer height are generally regarded as the main factors influencing the diurnal cycle of surface $\mathrm{O}_{3}$. Previous studies have reported that high levels of surface $\mathrm{O}_{3}$ were associated with high wind speeds and high mixing heights on the TP. In addition, local photochemical production may also contribute to the higher concentration of $\mathrm{O}_{3}$ in the daytime (Tang et al., 2002; Yin et al., 2017b). Furthermore, Temperature can influence $\mathrm{O}_{3}$ production by accelerating the chemical reaction rate and increasing the VOCs (e.g., isoprene) emission (Coates et al., 2016), thus $\mathrm{O}_{3}$ increases with temperature (Abeleira and Farmer, 2017). On the TP, $\mathrm{O}_{3}$ concentration showed same diurnal variation with other studies conducted at Nam Co, Dangxiong, and Lhasa (Ran et al., 2014; Lin et al., 2015; Yin et al., 2017b). However, surface $\mathrm{O}_{3}$ at NCO-P and Waliguan showed different patterns because thermal circulation and mountain-valley breeze were the most influential factors in two regions respectively (Cristofanelli et al., 2010; Xue et al., 2011).

\section{Correlations between Air Pollutants}

The Pearson correlation coefficients (R) between pollutants were calculated for each of the six cities (Table 3). Over the 1-year period, $\mathrm{PM}_{2.5}$ was positively correlated with $\mathrm{PM}_{10}, \mathrm{CO}, \mathrm{SO}_{2}$, and $\mathrm{NO}_{2}$ in all six cities, especially in Lhasa and Nyingchi $(\mathrm{R}>0.5)$, thus suggesting their common sources from biomass (e.g., yak dung, woods, crop straw) burning and fossil fuel combustion such as vehicle emission. For Lhasa city, high mountains situate at its south and north sides making difficult for pollutants to diffuse when atmosphere is relatively stable, thus causing high correlations among $\mathrm{PM}_{2.5}$ and other pollutants (Li et al., 2018). Nyingchi covered mainly by alpine forest, therefore, biogenic emissions, local woods burning for cooking and heating, and vehicle consumption may be essential sources of PM and gas pollutants. Positive correlations with slightly weaker $\mathrm{R}$ values between $\mathrm{PM}_{2.5}$ and other pollutants were observed in other cities, which might imply influence of dust or weather condition. For example, Ngari is located in a place with relatively open geomorphological setting and was classified as barren region according to MODIS land cover classification (Liu et al., 2017a). Relatively weak correlations among these pollutants implied a disturbance of PM masses from dust impact (Liu et al., 2017a). Previous studies have reported frequent dust plumes in the lower atmosphere in the western TP which can possibly impact the distribution of aerosol masses of TP (Huang et al., 2007).

In this study, $\mathrm{O}_{3}$ was negatively correlated with the other pollutants with low $(-0.25<\mathrm{R}<0)$ to moderate $(-0.5 \leq \mathrm{R}$ $\leq-0.25)$ correlation coefficients. $\mathrm{O}_{3}$ can be affected by lots

Table 3. Correlations of pollutants in six cities of the TP based on annual data during 2016-2017.

\begin{tabular}{|c|c|c|c|c|c|c|c|c|c|c|}
\hline & $\mathrm{PM}_{10}$ & $\mathrm{SO}_{2}$ & $\mathrm{NO}_{2}$ & $\mathrm{CO}$ & $8 \mathrm{hO}_{3}$ & $\mathrm{PM}_{10}$ & $\mathrm{SO}_{2}$ & $\mathrm{NO}_{2}$ & $\mathrm{CO}$ & $8 \mathrm{hO}_{3}$ \\
\hline & \multicolumn{5}{|c|}{ Nagchu } & \multicolumn{5}{|c|}{ Lhasa } \\
\hline $\mathrm{PM}_{2.5}$ & 0.45 & 0.52 & 0.62 & 0.76 & -0.25 & 0.85 & 0.71 & 0.76 & 0.78 & -0.49 \\
\hline $\mathrm{PM}_{10}$ & & 0.48 & 0.53 & 0.51 & -0.33 & & 0.69 & 0.84 & 0.80 & -0.45 \\
\hline $\mathrm{SO}_{2}$ & & & 0.43 & 0.51 & -0.24 & & & 0.65 & 0.81 & -0.46 \\
\hline $\mathrm{NO}_{2}$ & & & & 0.54 & -0.28 & & & & 0.79 & -0.49 \\
\hline \multirow[t]{2}{*}{$\mathrm{CO}$} & & & & & -0.21 & & & & & -0.45 \\
\hline & \multicolumn{5}{|c|}{ Shigatse } & \multicolumn{5}{|c|}{ Qamdo } \\
\hline $\mathrm{PM}_{2.5}$ & 0.78 & 0.37 & 0.49 & 0.54 & -0.41 & 0.65 & 0.40 & 0.47 & 0.42 & -0.33 \\
\hline $\mathrm{PM}_{10}$ & & 0.34 & 0.44 & 0.52 & -0.46 & & 0.36 & 0.39 & 0.49 & -0.22 \\
\hline $\mathrm{SO}_{2}$ & & & 0.34 & 0.45 & -0.27 & & & 0.27 & 0.39 & -0.32 \\
\hline $\mathrm{NO}_{2}$ & & & & 0.44 & -0.32 & & & & 0.57 & -0.30 \\
\hline \multirow[t]{2}{*}{$\mathrm{CO}$} & & & & & -0.34 & & & & & -0.34 \\
\hline & \multicolumn{5}{|c|}{ Ngari } & \multicolumn{5}{|c|}{ Nyingchi } \\
\hline $\mathrm{PM}_{2.5}$ & 0.55 & 0.47 & 0.41 & 0.56 & -0.22 & 0.53 & 0.58 & 0.67 & 0.65 & -0.11 \\
\hline $\mathrm{PM}_{10}$ & & 0.39 & 0.30 & 0.36 & -0.15 & & 0.44 & 0.46 & 0.50 & -0.14 \\
\hline $\mathrm{SO}_{2}$ & & & 0.23 & 0.53 & -0.11 & & & 0.40 & 0.46 & -0.21 \\
\hline $\mathrm{NO}_{2}$ & & & & 0.37 & -0.26 & & & & 0.40 & -0.11 \\
\hline $\mathrm{CO}$ & & & & & -0.23 & & & & & -0.18 \\
\hline
\end{tabular}


of factors (Zhang et al., 2015; Derwent et al., 2016; Yin et al., 2017b; Gong et al., 2018), thus it is difficult to identify the exact impact factor here. However, previous studies reported that in the northern $\mathrm{TP}$, horizontal and vertical wind transports were considered as major contributors to surface $\mathrm{O}_{3}$ (Shen et al., 2014). Whereas titration of $\mathrm{O}_{3}$ by $\mathrm{NO}_{\mathrm{X}}$ as well as the differences in altitude and meteorology such as photochemistry are main factors affecting surface $\mathrm{O}_{3}$ in the central TP (Ran et al., 2014). In addition, frequent stratospheric intrusions were recorded in all seasons except spring along the southern ridge of the Himalaya, which might be the major factors (Cristofanelli et al., 2010). Therefore, surface $\mathrm{O}_{3}$ on TP may dominate by mixed processes involving photochemical reactions, vertical mixing and downward transport of stratospheric air mass which caused different correlations with other pollutants.

\section{CONCLUSION}

This study analyzed the spatial and temporal variations of $\mathrm{PM}_{2.5}, \mathrm{PM}_{10}, \mathrm{SO}_{2}, \mathrm{NO}_{2}, \mathrm{CO}$, and $\mathrm{O}_{3}$ observed in six cities on the TP from June 2016 to May 2017. This was done to gain a deep understanding of the pollution levels of different pollutants, evaluate the attainment of air quality standards in various cities, and mark the seasonal variation of major pollutants. High concentrations of $\mathrm{PM}_{2.5}, \mathrm{PM}_{10}$, $\mathrm{SO}_{2}, \mathrm{NO}_{2}$, and $\mathrm{CO}$ were observed in Nagchu and Lhasa, especially during winter, indicating a strong contribution of anthropogenic activities. Beside long-range transport pollutants from surrounding regions, local emissions (e.g., biomass burning, religious activities) also contributed much to the atmospheric pollutants in the study region. However, pollutants in other cities, especially in Nagri and Nyingchi, met the newly revised ambient air quality standards (Grade I), indicating that even though some cities were affected by anthropogenic emissions, the air conditions in most regions were good and still can be looked as background sites. Seasonal variations of all pollutants except $\mathrm{O}_{3}$ were observed, with the highest concentrations in winter followed by fall, spring, and summer, in descending order. Weather conditions and emission sources are main factors influencing the seasonal variation of these pollutants. However, opposite $\mathrm{O}_{3}$ variation was observation with other pollutants due to the combined influence of stratospheric intrusion, solar radiation and weather conditions. The diurnal trends of $\mathrm{PM}_{2.5}, \mathrm{PM}_{10}, \mathrm{SO}_{2}, \mathrm{NO}_{2}$, and $\mathrm{CO}$ concentrations in the TP generally exhibited two peaks around noon and midnight, whereas $\mathrm{O}_{3}$ concentrations were similar among the six regions, with the maximum in the afternoon. Positive correlations were observed between $\mathrm{PM}_{2.5}$ and other pollutants (e.g., $\mathrm{PM}_{10}, \mathrm{SO}_{2}, \mathrm{NO}_{2}$, and $\mathrm{CO}$ ), indicating that these pollutants might have common sources or experience similar chemical process. However, surface $\mathrm{O}_{3}$ exhibited negative correlations with other pollutants because of combined influences on it.

\section{ACKNOWLEDGEMENTS}

This study is supported by the National Natural Science
Foundation of China (41705132) Strategic Priority Research Program of Chinese Academy of Sciences, Pan-Third Pole Environment Study for a Green Silk Road (Pan-TPE) (XDA20040501), CAS "Light of West China" Program and State Key Laboratory of Cryospheric Science (SKLCSOP-2018-01). The manuscript has been edited by Wallace Academic Editing.

\section{REFERENCES}

Abeleira, A.J. and Farmer, D.K. (2017). Summer ozone in the northern Front Range metropolitan area: weekendweekday effects, temperature dependences and the impact of drought. Atmos. Chem. Phys. 17: 6517-6529.

Atkinson, R. (2000). Atmospheric chemistry of VOCs and $\mathrm{NO}_{\mathrm{x}}$. Atmos. Environ. 34: 2063-2101.

Bapna, M. (2012). Toward an environmentally sustainable future: Country environmental analysis of the People's Republic of China. The Asian Development Bank, Manila, Philippines.

Cao, Z.Q., Sheng, L.F., Liu, Q., Yao, X.H. and Wang, W.C. (2015). Interannual increase of regional haze-fog in North China Plain in summer by intensified easterly winds and orographic forcing. Atmos. Environ. 122: 154-162

Chai, F.H., Gao, J., Chen, Z.X.,Wang, S.L., Zhang, Y.C., Zhang, J.Q., Zhang, H.F., Yun, Y.R. and Ren, C. (2014). Spatial and temporal variation of particulatematter and gaseous pollutants in 26 cities in China. J. Environ. Sci. 26: 75-82.

Chan, C.K. and Yao, X. (2008). Air pollution in mega cities in China. Atmos. Environ. 42: 1-42.

Chan, C.Y. and Chan, L.Y. (2000). Effect ofmeteorology and air pollutant transport on ozone episodes at a subtropical coastal Asian city, Hong Kong. J. Geophys. Res. 105: 20707-20724.

Chen, P.F., Kang, S.C., Bai, J.K., Sillanpää, M. and Li, C.L. (2015). Yak dung combustion aerosols in the Tibetan Plateau: Chemical characteristics and influence on the local atmospheric environment. Atmos. Res. 156: 58-66.

Chen, P.F., Kang, S.C., Li, C.L., Li, Q.L., Yan, F.P., Guo, J.M., Ji, Z.M., Zhang, Q.G., Hu, Z.F., Tripathee, L. and Sillanpää, M. (2018a). Source appostionment and risk assessment of atmospheric polycyclic aromatic hydrocarbons in Lhasa, Tibet, China. Aerosol Air Qual. Res. 18: 1294-1304.

Chen, P.F., Li, C.L., Kang, S.C., Rupakheti, M., Panday, A.K., Yan, F.P., Li, Q.L., Zhang, Q.G., Guo, J.M., Ji, Z.M., Rupakheti, D. and Luo, W. (2017). Characteristics of particulate-phase polycyclic aromatic hydrocarbons (PAHs) in the atmosphere over the central Himalayas. Aerosol Air Qual. Res. 17: 2942-2954.

Chen, X.T. Kang, S.C., Cong, Z.Y., Yang, J.H. and Ma, Y.M. (2018b). Concentration, temporal variation, and sources of black carbon in the Mt. Everest region retrieved by real-time observation and simulation. Atmos. Chem. Phys. 18: 12859-12875.

Cheng, H.R., Wang, Z.W., Feng, J.L., Chen, H.L., Zhang, 
F. and Liu, J. (2012). Carbonaceous species composition and source apportionment of $\mathrm{PM}_{2.5}$ in urban atmosphere of Wuhan. Ecol. Environ. Sci. 21: 1574-1579.

Coates, J., Mar, K.A., Ojha, N. and Butler, T.M. (2016). The influence of temperature on ozone production under varying $\mathrm{NO}_{\mathrm{x}}$ conditions-A modeling study. Atmos. Chem. Phys. 16: 11601-11615.

Cong, Z.Y., Kang, S.C., Kawamura, K., Liu, B., Wan, X., Wang, Z.Y., Gao, S.P. and Fu, P.Q. (2015). Carbonaceous aerosols on the south edge of the Tibetan Plateau: Concentrations, seasonality and sources. Atmos. Chem. Phys. 15: 1573-1584.

Cristofanelli, P., Bracci, A., Sprenger, M., Marinoni, A., Bonafe, U., Calzolari, F., Duchi, R., Laj, P., Pichon, J.M., Roccato, F., Venzac, H., Vuillermoz., E. and Bonasoni, P. (2010). Tropospheric ozone variations at the Nepal Climate Observatory-Pyramid (Himalayas, $5079 \mathrm{~m}$ a.s.l) and influence of deep stratospheric intrusion events. Atmos. Chem. Phys. 10: 6537-6549.

Cui, L., Ni, C.J., Wang, C., Xie, Y.Z., Hu, S.P. and Gan, X.L. (2015). Temporal variation of ozone concentration and impact factors in Chengdu. Environ. Monit. China 31: 41-46.

Decesari, S., Facchini, M. C., Carbone, C., Giulianelli, L., Rinaldi, M., Finessi, E., Fuzzi, S., Marinoni, A., Cristofanelli, P., Duchi, R., Bonasoni, P., Vuillermoz, E., Cozic, J., Jaffrezo, J.L. and Laj, P. (2010). Chemical composition of $\mathrm{PM}_{10}$ and $\mathrm{PM}_{1}$ at the high-altitude Himalayan station Nepal Climate Observatory-Pyramid (NCO-P) (5079 m a.s.1.). Atmos. Chem. Phys. 10: 45834596.

Derwent, R.G., Parrish, D.D., Galbally, I.E., Stevenson, D.S., Doherty, R.M., Young, P.J. and Shallcross. D.E. (2016). Interhemispheric differences in seasonal cycles of trospheric ozone in the marine boundary layer: Observation-model comparisons. J. Geophys. Res. 121: 11075-11085.

Ding, H., Liu, Y.H., Yu, Z., Cheung, C. and Zhan, J.M. (2017). Spatial and temporal characteristics and main contributing regions of high $\mathrm{PM}_{2.5}$ pollution in Hong Kong. Aerosol Air Qual. Res. 17: 2955-2965.

Du, Y.J. and Li, T.T. (2016). Assessment of health-based economic costs linked to fine particulate $\left(\mathrm{PM}_{2.5}\right)$ pollution: A case study of haze during January 2013 in Beijing, China. Air Qual. Atmos. Health 9: 439-445.

Forouzanfar, M.H., Afshin, A., Alexander, L.T., Anderson, H.R. and Bhutta, Z.A. (2016). Global, regional, and national comparative risk assessment of 79 behavioral, environmental and occupational, and metabolic risks or clusters of risks, 1990-2015: A systematic analysis for the Global Burden of Disease Study 2015. Lancet 388: 1659-1724.

Gong, P., Wang, X.P. and Yao, T. (2011). Ambient distribution of particulate- and gas-phase $n$-alkanes and polycyclic aromatic hydrocarbons in the Tibetan Plateau. Environ. Earth Sci. 64: 1703-1711.

Gong, P., Wang, X.P., Xue, Y.G., Sheng, J.J., Gao, S.P., Tian, L.D. and Yao, T.D. (2015). Influence of atmospheric circulation on the long-range transport of organochlorine pesticides to the Western Tibetan Plateau. Atmos. Res. 166: 157-164.

Gong, X., Hong, S. and Jaffe, D.A. (2018). Ozone in China: Spatial distribution and leading meteorological factors controlling $\mathrm{O}_{3}$ in 16 Chinese cities. Aerosol Air Qual. Res. 18: 2287-2300.

Guan, Q.Y., Cai, A.,Wang, F.F., Yang, L.Q., Xu, C.Q. and Liu, Z.Y. (2017). Spatio-temporal variability of particulate matter in the key part of Gansu Province, Western China. Environ. Pollut. 230: 189-198.

Guo, S., Hu, M., Zamora, M.L., Peng, J.F., Shang, D.J., Zheng, J., Du, Z.F.,Wu, Z.J., Shao, M., Zeng, L.M., Molina, M.J. and Zhang, R.Y. (2014). Elucidating severe urban haze formation in China. Proc. Natl. Acad. Sci. U.S.A. 111: 17373-17378.

He, J.J., Gong, S.L., Yu, Y., Yu, L.J.,Wu, L., Mao, H.J., Song, C.B., Zhao, S.P., Liu, H.L., Li, X.Y. and Li, R.P. (2017). Air pollution characteristics and their relation tometeorological conditions during 2014-2015 in major Chinese cities. Environ. Pollut. 223: 484-496.

Hu, J.L., Wang, Y.G., Ying, Q. and Zhang, H.L. (2014). Spatial and temporal variability of $\mathrm{PM}_{2.5}$ and $\mathrm{PM}_{10}$ over the North China Plain and the Yangtze River Delta, China. Atmos. Environ. 95: 598-609.

Huang, F.F., Li, X., Wang, C., Xu, Q., Wang, W., Luo, Y.X., Tao, L.X., Gao, Q., Guo, J., Chen, S.P., Cao, K., Liu, L., Gao, N., Liu, X.T., Yang, K., Yan, A.S. and Guo, X.H. (2015). $\mathrm{PM}_{2.5}$ spatiotemporal variations and the relationship with meteorological factors during 2013-2014 in Beijing, China. PLoS One 10: e0141642.

Huang, J.P., Minnis, P., Yi, Y.H., Tang, Q., Wang, X., Hu, Y.X., Liu, Z.Y., Ayers, K., Trepte, C. and Winker, D. (2007). Summer dust aerosols detected from CALIPSO over the Tibetan Plateau. Geophys. Res. Lett. 34: L18805.

Ji, Z.M., Kang, S.C., Cong, Z.Y., Zhang, Q.G. and Yao, T.D. (2015). Simulation of carbonaceous aerosols over the Third Pole and adjacent regions: Distribution, transportation, deposition, and climatic effects. Clim. Dyn. 45: 2831-2846.

Jia, B., Wang, Y., Yao, Y. and Xie, Y. (2015). A new indicator on the impact of large-scale circulation on wintertime particulate matter pollution over China. Atmos. Chem. Phys. 15: 11919-11929.

Kang, J.E., Song, S.K., Lee, H.W. and Kim, Y.K. (2012). The influence of meteorological conditions and complex topography on ozone concentrations in a valley area near coastal metropolitan cities. Terr. Atmos. Ocean. Sci. 23: 25-38.

Kang, S.C., Li, C.L., Wang, F.Y., Zhang, Q.G. and Cong, Z.Y. (2009). Total suspended particulate matter and toxic elements indoors during cooking with yak dung. Atmos. Environ. 43: 4243-4246.

Kang, S.C., Chen, P.F., Li, C.L., Liu, B. and Cong, Z.Y. (2016). Atmospheric aerosol elements over the inland Tibetan Plateau: Concentration, seasonality, and transport, Aerosol Air Qual. Res. 16: 789-800.

Kim, S., Jeong, D., Sanchez, D., Wang, M., Seco, R., Blake, D., Meinardi, S., Barletta, B., Hughes, S., Jung, J.S., Kim, D., Lee, G., Lee, M., Ahn, J., Lee, S.D., Cho, 
G., Sun, M.Y., Lee, Y.H. and Park, R. (2018). The controlling factors of photochemical ozone production in Seoul, South Korea. Aerosol Air Qual. Res. 18: 22532261.

Landrigan, P.J. (2016). Air pollution and health. Lancet Pub. Health 2: e4-e5.

Li, C.L., Kang, S.C., Chen, P.F., Zhang, Q.G. and Fang, G.C. (2012). Characterizations of particle-bound trace metals and polycyclic aromatic hydrocarbons (PAHs) within Tibetan tents of South Tibetan Plateau, China. Environ. Sci. Pollut. Res. 19: 1620-1628.

Li, C.L., Bosch, C., Kang, S.C., Andersson, A., Chen, P.F., Zhang, Q.G., Cong, Z.Y., Chen,B., Qin, D.H. and Gustafsson, Ö. (2016a). Sources of black carbon to the Himalayan-Tibetan Plateau glaciers. Nat. Commun. 7: 12574.

Li, C.L., Chen, P.F., Kang, S.C., Yan, F.P., Hu, Z.F., Qu, B. and Sillanpää, M. (2016b). Concentrations and light absorption characteristics of carbonaceous aerosol in $\mathrm{PM}_{2.5}$ and $\mathrm{PM}_{10}$ of Lhasa city, the Tibetan Plateau. Atmos. Environ. 127: 340-346.

Li, C.L., Han, X, W., Kang, S.C., Yan, F.P., Chen, P.F., Hu, Z.F., Yang, J.H., Ciren, D., Gao, S.P., Sillanpää, M. Han, Y.M., Cui, Y.Y., Liu, S. and Smith, K.R. (2018). Heavy near-surface $\mathrm{PM}_{2.5}$ pollution in Lhasa, China during a relatively static winter period. Chemosphere 214: 314-318.

Li, G.H., Bei, N.F., Cao, J.J., Wu, J.R., Long, X., Feng, T., Dai,W.T., Liu, S.X., Zhang, Q. and Tie, X.X. (2017). Widespread and persistent ozone pollution in eastern China during the non-winter season of 2015: Observations and source attributions. Atmos. Chem. Phys. 17: 2759-2774.

Li, M.H., Song, Y., Mao, Z.C., Liu, M.X. and Huang, X. (2016c). Impacts of thermal circulations induced by urbanization on ozone formation in the Pearl River Delta region, China. Atmos. Environ. 127: 382-392.

Li, Q. and Wang, C. (2014). Research on urbanization in Tibet and its environmental impact. Chin. Soft Sci. 12: 70-78 (in Chinese).

Lin, C.Q., Li, Y., Lau, A.K., Li, C.C. and Fung, J.H. (2018). 15-year $\mathrm{PM}_{2.5}$ trends in the Pearl River Delta region and Hong Kong from satellite observation. Aerosol Air Qual. Res. 18: 2355-2362.

Lin, W., Xu, X., Zheng, X., Dawa, J., Baima, C. and Ma, J. (2015). Two-year measurements of surface ozone at Dangxiong, a remote highland site in the Tibetan Plateau. J. Environ. Sci. 31: 133-145.

Liu, B., Cong, Z.Y., Wang, Y.S., Xin, J.Y., Wan, X., Pan, Y.P., Liu, Z.R., Wang, Y.H., Zhang, G.S., Wang, Z.Y., Wang, Y.J. and Kang, S.C. (2017a). Backgroud aerosol over the Himalayas and Tibetan Plateau: Observed characteristics of aerosol mass loading. Atmos. Chem. Phys. 17: 449-463.

Liu, M.M., Huang, Y.N., Ma, Z.W., Jin, Z., Liu, X.Y.,Wang, H.K., Liu, Y.,Wang, J.N., Jantunen, M., Bi, J. and Kinney, P.L. (2017b). Spatial and temporal trends in themortality burden of air pollution in China: 2004-2012. Environ. Int. 98: 75-81.
Liu, Z., Liu, D., Huang, J., Vaughan, M., Uno, I., Sugimoto, N., Kittaka, C., Trepte, C.,Wang, Z., Hostetler, C. and Winker, D. (2008). Airborne dust distributions over the Tibetan Plateau and surrounding areas derived from the first year of CALIPSO lidar observations. Atmos. Chem. Phys. 8: 5045-5060.

Lüthi, Z., Škerlak, B., Kim, S., Lauer, A., Mues, A., Rupakheti, M. and Kang, S. (2015). Atmospheric brown clouds reach the Tibetan Plateau by crossing the Himalayas. Atmos. Chem. Phys. 15: 1-15.

Ma, X.Y. and Jia, H.L. (2016). Particulatematter and gaseous pollutions in three megacities over China: Situation and implication. Atmos. Environ. 140: 476-494.

Ran, L., Lin, W.L., Deji, Y.Z., La, B., Tsering, P.M., Xu, X.B. and Wang, W. (2014). Surface gas pollutants in Lhasa, a highland city of Tibet-current levels and pollutants implications. Atmos. Chem. Phys. 14: 1072110730

Shen, Z., Cao, J., Zhang, L., Zhao, Z., Dong, J., Wang, L., Wang, Q., Li, G., Liu, S. and Zhang, Q. (2014). Characteristics of surface $\mathrm{O}_{3}$ over Qinghai Lake area in Northeast Tibetan Plateau, China. Sci. Total Environ. 500: 295-301.

Shu, L., Xie, M.,Wang, T., Gao, D., Chen, P., Han, Y., Li, S., Zhuang, B. and Li, M. (2016). Integrated studies of a regional ozone pollution synthetically affected by subtropical high and typhoon system in the Yangtze River Delta region, China. Atmos. Chem. Phys. 16: 15801-15819.

Song, C.B., He, J.J., Wu, L., Jin, T.S., Chen, X., Li, R.P., Ren, P.P., Zhang, L. and Mao, H.J. (2017a). Health burden attributable to ambient $\mathrm{PM}_{2.5}$ in China. Environ. Pollut. 223: 575-586.

Song, C.B.,Wu, L., Xie, Y.C., He, J.J., Chen, X.,Wang, T., Lin, Y.C., Jin, T.S.,Wang, A.X., Liu, Y., Dai, Q.L., Liu, B.S., Wang, Y.N. and Mao, H.J. (2017b). Air pollution in China: Status and spatiotemporal variations. Environ. Pollut. 227: 334-347.

Tai, A.P., Mickley, L.J. and Jacob, D.J. (2010). Correlations between fine particulate matter $\left(\mathrm{PM}_{2.5}\right)$ and meteorological variables in the United States: Implications for the sensitivity of $\mathrm{PM}_{2.5}$ to climate change. Atmos. Environ. 44: 3976-3984.

Tan, J.H., Duan, J.C., Zhen, N.J., He, K.B. and Hao, J.M. (2016). Chemical characteristics and source of sizefractionated atmospheric particle in haze episode in Beijing. Atmos. Res. 167: 24-33

Tang, J., Zhou, L.X., Zheng, X.D., Zhou, X.J., Shi, G.Y. and Suoluo, D.J. (2002). The observational study of surface ozone at Lhasa suburb in summer 1998. Acta Meteorol. Sinica 60: 221-229. (in Chinese with English Abstract)

Tao, J., Gao, J., Zhang, L., Zhang, R., Che, H., Zhang, Z., Lin, Z., Jing, J., Cao, J. and Hsu, S,C. (2014). PM $_{2.5}$ pollution in a megacity of southwest China: Source apportionment and implication. Atmos. Chem. Phys. 14: 8679-8699.

Tie, X.X., Madronich, S., Li, G.H., Ying, Z.M., Zhang, R.Y., Garcia, A.R., Lee-Taylor, J. and Liu, Y.B. (2007). 
Characterizations of chemical oxidants in Mexico City: A regional chemical dynamical model (WRF-Chem) study. Atmos. Environ. 41: 1989-2008.

Wan, X., Kang, S.C., Xin, J.Y., Liu, B., Wen, T.X., Wang, P.L., Wang, Y.S. and Cong, Z.Y. (2016). Chemical composition of size-segregated aerosols in Lhasa city, Tibetan Plateau. Atmos. Res. 174: 142-150.

Wang, T., Xue, L.K., Brimblecombe, P., Lam, Y.F., Li, L. and Zhang, L. (2017). Ozone pollution in China: A review of concentrations, meteorological influences, chemical precursors, and effects. Sci. Total Environ. 575: 1582-1596.

Wang, W.W., Cui, K.P., Zhao, R., Hsieh, L.T. and Lee, W.J. (2018). Characterization of the air quality index for Wuhu and Bengbu cities, China. Aerosol Air Qual. Res. 18: $1198-1220$.

Wang, Y.G., Ying, Q., Hu, J.L. and Zhang, H.L. (2014). Spatial and temporal variations of six criteria air pollutants in 31 provincial capital cities in China during 2013-2014. Environ. Int. 73: 413-422.

Wang, Z.B., Hu, M., Wu, Z.J. and Yue, D.L. (2013). Long-term measurements of particle number size distributions and the relationships with air mass history and source apportionment in the summer of Beijing. Atmos. Chem. Phys. 13: 10159-10170.

Wu, G.M., Wan, X., Gao, S.P., Fu, P.Q., Yin, Y.G., Li, G., Zhang, G.S., Kang, S.C., Ram, K. and Cong, Z.Y. (2018). Humic-like substances (HULIS) in aerosols of central Tibetan Plateau (Nam Co, $4730 \mathrm{~m}$ asl): Abundance, light absorption properties, and sources. Environ. Sci. Technol. 52: 7203-7211.

Xia, X.G., Wang, P.C., Wang, Y.S., Li, Z.Q., Xin, J.Y., Liu, J. and Chen, H.B. (2008). Aerosol optical depth over the Tibetan Plateau and its relation to aerosols over the Taklimakan Desert. Geophys. Res. Lett. 35: L16804.

Xiao, Q.Y., Saikawa, E., Yokelson, R.J., Chen, P.F., Li, C.L. and Kang, S.C. (2015). Indoor air pollution from burning yak dung as a household fuel in Tibet. Atmos. Environ. 102: 406-412.

Xie, Y.G., Zhao, B., Zhang, L. and Luo, R. (2015). Spatiotemporal variations of $\mathrm{PM}_{2.5}$ and $\mathrm{PM}_{10}$ concentrations between 31 Chinese cities and their relationships with $\mathrm{SO}_{2}, \mathrm{NO}_{2}, \mathrm{CO}$ and $\mathrm{O}_{3}$. Particuology 20: 141-149.

Xu, G., Jiao, L.M., Zhang, B.E., Zhao, S.L., Yuan, M., Gu, Y.Y., Liu, J.F. and Tang, X. (2017). Spatial and temporal variability of the $\mathrm{PM}_{2.5} / \mathrm{PM}_{10}$ ratio in Wuhan, Central China. Aerosol Air Qual. Res. 17: 741-751.

Xu, X., Zhao, T., Liu, F., Gong, S.L., Kristovich, D., Lu, C., Guo, Y., Cheng, X., Wang, Y. and Ding, G. (2016). Climate modulation of the Tibetan Plateau on haze in China. Atmos. Chem. Phys. 16: 1365-1375.

Xue, L., Wang, T., Zhang, X., Poon, C., Ding, A., Zhou, X., Wu, W., Tang, J. and Zhang, Q. (2011). Source of surface ozone and reactive nitrogen speciation at Mount Waliguan in Western China. J. Geophys. Res. 116: D07306.

Yang, J.H., Kang, S.C., Ji, Z.M. and Chen, D.L. (2018). Modeling the origin of anthropogenic black carbon and its climatic effect over the Tibetan Plateau and surrounding regions. J. Geophys. Res. 123: 671-692.

Yang, J.H., Kang, S.C., Ji, Z.M., Yang, S.X., Li, C.L. and Tripathee, L. (2019). Vital contribution of residential emissions to atmospehric fine particles $\left(\mathrm{PM}_{2.5}\right)$ during the severe wintertime pollution episodes in Western China. Environ. Pollut. 245: 519-530.

Yang, Y.J., Zhou, R., Yan, Y., Yu, Y., Liu, J.Q., Di, Y.A., $\mathrm{Du}, \mathrm{Z} . \mathrm{Y}$. and $\mathrm{Wu}, \mathrm{D}$. (2016). Seasonal variations and size distributions of water-soluble ions of atmospheric particulate matter at Shigatse, Tibetan Plateau. Chemosphere 145: 560-567.

Yin, D.Y., Zhao, S.P. and Qu, J.J. (2017a). Spatial and seasonal variations of gaseous and particulate matter pollutants in 31 provincial capital cities, China. Air Qual. Atmos. Health 10: 359-370.

Yin, X.F., Kang, S.C., Foy, B., Cong, Z.Y., Luo, J.L., Zhang, L., Ma, Y.M., Zhang, G.S., Rupakheti, D. and Zhang, Q.G. (2017b). Surface ozone at Nam Co in the inland Tibetan Plateau: variation, synthesis comparison and regional representativeness. Atmos. Chem. Phys. 17: 11293-11311.

Zhang, H.F.,Wang, Z.H. and Zhang, W.Z. (2016). Exploring spatiotemporal patterns of $\mathrm{PM}_{2.5}$ in China based on ground-level observations for 190 cities. Environ. Pollut. 216: 559-567.

Zhang, L., Jin, L., Zhao, T., Yin, Y., Zhu, B., Shan, Y., Guo, X., Tan, C., Gao, J. and Wang, H. (2015). Diurnal variation of surface ozone in mountainous areas: Case study of Mt. Huang, East China. Sci. Total Environ. 538: 583-590.

Zhang, Q., Streets, D.G., Carmichael, G.R., He, K.B., Huo, H., Kannari, A., Klimont, Z., Park, I.S., Reddy, S., Fu, J.S., Chen, D., Duan, L., Lei, Y., Wang, L.T. and Yao, Z.L. (2009). Asian emissions in 2006 for the NASA INTEX-B mission. Atmos. Chem. Phys. 9: 5131-5153.

Zhang, X.Y., Arimoto, R., Cao, J.J., An, Z.S. and Wang, D. (2001). Atmospheric dust aerosol over the Tibetan Plateau. J. Geophys. Res. 106: 18471-18476.

Zhang, Y.L and Cao, F. (2015). Fine particulate matter $\left(\mathrm{PM}_{2.5}\right)$ in China at a city level. Sci. Rep. 5: 14884.

Zhao, S.P., Yu, Y., Yin, D.Y., He, J.J., Liu, N., Qu, J.J. and Xiao, J.H. (2016). Annual and diurnal variations of gaseous and particulate pollutants in 31 provincial capital cities based on in situ air quality monitoring data from China National Environmental Monitoring Center. Environ. Int. 86: 92-106.

Zhao, S.P., Yu, Y., Yin, D.Y., Qin, D.H., He, J.J. and Dong, L.X. (2018). Spatial patterns and temporal variations of six criteria air during 2015 to 2017 in the city clusters of Sichuan Basin, China. Sci. Total Environ. 624: 540-557.

Zheng, X.Y., Fu, Y.F., Yang, Y.J. and Liu, G.S. (2015). Impact of atmospheric circulations on aerosol distributions in autumn over Eastern China: Observational evidence. Atmos. Chem. Phys. 15: 12115-12138

Zheng, Y., Stevenson, K.J., Barrowcliffe, R., Chen, S., Wang, H. and Barnes, J.D. (1998). Ozone levels in Chongqing: A potential threat to crop plants commonly 
grown in the region? Environ. Pollut. 99: 299-308.

Zhou, T.C., Sun, J. and Yu, H. (2017). Temporal and spatial patterns of China'smain air pollutants: Years 2014 and 2015. Atmosphere 8: 137.

Zhou, X., Cao, Z., Ma, Y., Wang, L., Wu, R. and Wang, W. (2016). Concentrations, correlations and chemical species of $\mathrm{PM}_{2.5} / \mathrm{PM}_{10}$ based on published data in China:
Potential implications for the revised particulate standard. Chemosphere 144: 518-526.

Received for review, November 13, 2018

Revised, January 3, 2019 Accepted, February 18, 2019 